DE DE GRUYTER OPEN
Research Article

(C) 2018 Veiga-Neto et.al. This is an open access article licensed under the Creative Commons Attribution-NonCommercial-NoDerivs License (http://creativecommons.org/licenses/by-nc-nd/3.0/).

\title{
Environmental Favorability: Evidence in the Brazilian Context of Consumer Generations
}

\author{
Dr. Alipio Ramos Veiga-Neto \\ Potiguar University - Laureate International Universities
}

Ms. Nilo Lourival Ferreira Junior

Potiguar University - Laureate International Universities

Dr. ${ }^{a}$ Cristine Hermann Nodari

Potiguar University - Laureate International Universities

\section{Ms. Ana Lucia Brenner Barreto Miranda}

Potiguar University - Laureate International Universities

Doi: $10.2478 / \mathrm{mjss}-2018-0017$

\begin{abstract}
This study aimed to analyze the variables of environmental favorability, identifying and comparing their importance and differences within the consumers of the segments of the Baby Boomers, $X, Y$ and $Z$ generations in the Brazil. A factorial analysis showed that the highest averages found were related to the environmental responsibility of the companies and society. The lower averages are linked to the skepticism about advertising and advertising on labels of environmental products. The factors with higher scores refer to the environmental responsibility of society and the environmental conscience pointing out the concern of the interviewees about pollution, deforestation and the climatic consequences that can attack the environment. On the other hand, the lower averages are linked to the credibility in the environmental communication geared towards advertising and the veracity in the labels. Finally, the limitations and opportunities of future work are presented.
\end{abstract}

Keywords: Environmental favorability. Generations of consumption. Environment

\section{Introduction}

The environment has become a concern for society, raising the market for environmentally conscious people, consumers who are concerned with recycling the material in the purchase of organic products and the production process in which waste disposal is taken into account produced by the companies (Laroche, Bergeron \& Barbaro-Forleo, 2001). For Ottman (2012) the consumer inserted in this new model is called a conscious consumer, observer, who sees not only the product ready, but the consequences that will bring to the environment, from its production to the final destination. Thus, consumers are willing to pay more for an environmentally sound product, even if there are differences among demographic groups (Royne, Levy \& Marian, 2011).

With the emergence of this new market niche, the behavior of the new environmentally friendly society, with information that reaches consumers quickly through the media, and most 
recently of social network, comes to light. There is no consensus among the authors about age limits in terms of consumption generations. In this research, we chose age limits that are the focus of attention among the authors, being the generations of consumption classified in: Baby Boomers, existing in the period from 1941 to 1960; Generation X, for those born between 1961 and 1976; Generation Y, aimed at those who were born from 1977 to 1992; and Generation Z, valid for those born after 1992 (Foscht, Schloffer, Maloles \& Chia, 2009, Glass, 2007, Ladeira, 2010, Osajima, Sternquist \& Manjeshwar, 2010).

Environmental favorability is identified through consumer commitment to green consumption, in favor of the environment in which it lives. This consumption is seen as an element conducive to the environmentally healthy environment, with a view to promoting environmental sustainability and benefiting future generations. In this research, environmental favorability will be treated as synonymous with other terms, such as: green consumer, consumer environmentally friendly, consumer conscious, environmentally conscious consumer, environmentally friendly shopping. These terminologies, according to Romeiro (2010), follow in the same direction of the concept of environmental favorability.

This study aimed to analyze the variables of environmental favorability, identifying and comparing their importance and differences within the consumers of the segments of the Baby Boomers, $X, Y$ and $Z$ generations. Therefore, the question is: What are the differences presented by consumers generations in decision-making on environmental issues? To answer this question, it was necessary to identify the degree of importance of the variables of environmental favorability for the different generations of consumers; and to identify and analyze the factors that explain the variables of environmental favorability for four different generations of consumers.

In the current context, there is an increasing collection and concern about the environment, which is a source of research for some segments, such as: entrepreneurs who try to adapt to new consumers, marketing scholars who watch for new trends, and civil society that yearns for new information to adapt to the new environmentally friendly market (White, Macdonnell \& Ellard, 2012, Royne, Levy \& Marian, 2011, Levy \& Martinez, 2011, Thøgersen, Barcellos, Perin, Zhou, 2015). Environmental marketing researchers will seek new questions after identifying the differences between consumption generations in decision making. And finally, entrepreneurs who can direct their products by analyzing the differences found in this study and thus save on investments in the indication of products to reach a certain segment. With consumer stratification in generations and their consumption characteristics in conventional marketing, the interest of investigating how these generations behave in the ambit of environmental favorability is put into question.

\section{Consumer Behavior Favorable to the Environment}

The change in consumer behavior implies an increase in environmental awareness, resulting in an expansion of the demand for green products and, as such, being studied by several researchers worldwide. According to Schlegelmilch, Bohlen and Diamantopoulos (1996), companies should segment the market to feel how consumers behave in favor of the environment, however, previous studies have shown that personality, demographic and social indicators do not point to a shocking condition for changes in consumption. Straughan and Roberts (1999) found a profile of purchases in which the psychographic criterion, in detriment of the demographic criterion, has a greater weight in the consumer's decision, influencing the perception of the consumer of the purchase. Another finding of the authors is that it has more credibility the efficiency of the men in the combat to the aggressions to the environment, in comparison with the destruction that is caused to him.

With the greater ecological awareness of consumers, institutions have changed their postures, adopting a more effective and lasting sustainability conduct, in order to become more competitive in the market, stimulating the consumer to a greater green consumption. The care of companies with the conscious consumers has been felt, considering that it is a strong indicator in the decision to evaluate the companies that have social responsibility, apply the natural resources rationally and use ethical criteria in their activities (Instituto Akatu, 2013).

The care for the environment is becoming a panacea for the well-being of society, whose aspirations should be incorporated into corporate strategies in order to respond to expectations. 
According to Garcia et al. (2008), there is the emergence of a new market in which what is fashionable is the conscious consumption, by consumers demanding and influenced by organizations, green marketing and governmental actions that cover other values, including environmental, in their decisions to purchase services and goods. This demonstrates that the relationship between consumers and businesses is undergoing a process of transformation.

In the past, the consumer society had a greater concern with the qualities of the product and its price. According to Martinez (2010) and Wiernik, Ones and Dilchert (2013) the basic needs of consumers were placed in the foreground, unlike today, when consumers seek conscious consumption, without aggression to the environment and that is ethical, taking a broader view of the negative impacts caused to the planet and to its health, always in the search for more information that can base its attitudes towards the environment. For Ottman (2012), this search happens due to the desire to promote an education, of itself, regarding environmental issues.

\subsection{Segments by Generations}

Generational targeting becomes the basis for marketers to plot their strategies for competitive advantage. An interest in the comparison between the generations is perceived by the public. According to Williams and Page (2011), segmentation of the generations attracts the attention of many companies to suit the consumption preferences of each segment. For authors, different lifestyles, values, and demographics may influence purchasing decisions. Each generation has unique expectations and specific characteristics, regarding the temporal intervals of its growth, being noticed important events that can have influence in its decisions. The mentioned generations have homogenous traits within their individualities and are heterogeneous in other aspects. Generational living can occur in up to seven of them, in places like work, home and school.

As the consumer ages, his interests change as to the choice of a product. When researching on the intentions of purchases of young consumers, Madahi and Sukati (2012) assert that age has an inverse influence on consumption. The authors found that older people showed less intention to buy. In their conclusions, they emphasized that, generally, women are influenced by friends, who tend to contribute with greater encouragement to make purchases. Another considerable factor is consumer behavior, which often suffers from interference from cultural issues that may determine their choices. For other authors, higher schooling also has implications for the same consumer, making him / her more ecologically aware, and, in addition, the younger one is willing to pay more for nature-friendly products (McCrindle \& Wolfinger, 2014, Solomon, 2008, De Toni et al., 2013).

The Baby Boom Generation consists of children of parents who, after the Second World War, from 1939 to 1945, formed families. It is considered as the largest population generation among Americans, being of great importance to the country's economy. Its components are those people born between the years of 1941 and 1960. It is also an active and consumer generation, even spending up to $40 \%$ on accessories and household products. For Ottman (2012), baby boomers were the propellers of environmental consumerism, being the first generation to be ecologically conscious and concerned with the well-being and health of the consumer society, aiming at preserving the environment for the future generations (Glass, 2007, Solomon, 2008).

The Generation X are those born between the years 1961 and 1976, who are called Baby Busters and treated in American society as a supposed generation of alienation and laziness. However, in subsequent researches, it was shown that it is a diversified generation, possessing characteristics such as guarding part of the income, improvement of residences, through reforms, and individualistic and entrepreneurial vision (Solomon, 2008). Valuing the family is a priority for this group that, perhaps because they are children of separated parents, have become more careful parents. Because they have some financial restrictions, those in this group have their acquisitions based on more solid decisions (Vaz, 2011). Generation X is concerned about the environmental issue and the information that may arise due to modernity. For Feitosa (2009), those who are part of this generation are influenced by the Internet, but the way they use it is different from that of the younger generation, who is at a more productive age, with a generally stabilized professional life and bearing the materials as a way to achieve status.

Generation Y individuals are known as eco-boomers. For Kotler and Keller (2012), they 
demonstrate an interest in Internet gaming and interacting with others. It is a generation formed by those who were born between the years of 1977 to 1992, also being called "Millenials" and being able to be children of the Baby Boomers. This is a group close to Generation X, but with different characteristics. Some studies show that Generation $Y$ takes care of products and services that are beneficial to the environment, but that there is resistance on the part of these consumers regarding the adhesion of green products, a characteristic similar to that of young people from other countries (Mandhlazi, Dhurup \& Mafini, 2013). In a survey of young university students in Pakistan, Ali et al. (2011) found some skepticism about green products, in what refers to price and quality, although a positive attitude in the willingness to acquire them has been demonstrated.

The Generation $Z$ is made up of consumers who were born after 1992, the children of parents who later married and had a lower risk of divorce. It is a demanding, digital, consumerist group that does not show much brand loyalty at the time of purchase, giving preference to items that favor a good personal appearance and are in fashion. This generation emerges as an emerging consumer, requiring the attention of marketing operators, who need to establish strategies to captivate their many components, who like to shop malls, are consumers and have money to spend, always giving preference to known products in the market. Ceretta and Froemming (2011) argue that this generation is attracting the attention of marketers, who view young people as consumers connected with fashion, technology and the Internet.

In the study of the Akatu Institute (2002) on the conscious consumption of young Brazilians, entitled "Young People and Sustainable Consumption", some findings were listed, such as: a decisive criterion in the purchase was, for half of those surveyed, with the environment, health and employment; although it lives in a digital age, Generation $Z$ is not reached by environmental propaganda, nor does it feel manipulated by it, which does not prevent it from having an understanding of environmental issues thought by companies, taking into account, in their purchasing decisions, which have an environmentally responsible attitude (Garcia et al., 2008).

\section{Method}

Regarding classification, this research is characterized as descriptive and exploratory. The variables studied were grouped based on secondary research data on national and international themes that referred to the environmental favorability of the consumer as presented in Figure 1.

Figure 1: Variables found in the literature

\begin{tabular}{|c|c|}
\hline Theory & Variables \\
\hline $\begin{array}{l}\text { Mohr, Webb \& Harris } \\
(2001) \\
\text { Thogersen, Haugaard \& } \\
\text { Olesen (2010) }\end{array}$ & $\begin{array}{l}\text { Veracity of the advertisement, credibility of the advertisement, veracity of the packaging, } \\
\text { information of the label of the packaging, credibility of the packaging, detail of information on the } \\
\text { label, concern with the generation of trash, consequence of the trash for the society, interest on } \\
\text { the garbage issue. }\end{array}$ \\
\hline $\begin{array}{l}\text { Laroche, Bergeron } \\
\text { Barbaro-Forleo (2001) } \\
\text { Vaccari (2014) }\end{array}$ & $\begin{array}{l}\text { Waste separation, recycling of resource autonomy, environmental responsibility of the GES, } \\
\text { effort of all companies, pollution control, electricity saving, paper recycling, recycling for } \\
\text { wastewater reduction and pollutants, recycling for the reduction of deposits, price and } \\
\text { environment, competitive advantage, self esteem, sense of accomplishment, excitement, } \\
\text { security, altruism, love of the environment, socialization and self-sufficiency. }\end{array}$ \\
\hline Stern (1999) & $\begin{array}{l}\text { Climate change related to family, country and animal, disappearance of forests related family, } \\
\text { country and animals, toxic substances related to family, country and animals. }\end{array}$ \\
\hline Romeiro (2006) & Responsibility of the government, responsibility of the companies, responsibility of the consumer. \\
\hline Martinez (2010) & $\begin{array}{l}\text { Influence of advertising on purchasing decision (PD), influence on environmental advantage on } \\
\text { PD, influence of certification on PD, environmental impact of product on PD, influence of label on } \\
\text { PD, influence of friends on company on PD, influence of friends on environmentally responsible } \\
\text { product on PD. }\end{array}$ \\
\hline $\begin{array}{l}\text { Straughan \& Roberts } \\
\text { (1999) } \\
\text { Karna, Hansen \& Juslin } \\
(2003) \\
\text { Vaccari (2014) }\end{array}$ & $\begin{array}{l}\text { Ecological awareness, pro-ecological performance, ecological choice, preference for products } \\
\text { that save electricity, practice of saving electricity, effective actions in saving electricity, packaging } \\
\text { economy, preference for recyclable packaging, preference for recyclable products. }\end{array}$ \\
\hline \begin{tabular}{|lr} 
Veiga-Neto, & Filgueira \\
Vasconcelos $\quad \& \quad$ Almeic
\end{tabular} & Cha \\
\hline
\end{tabular}




\begin{tabular}{|l|l|}
\hline (2014) & $\begin{array}{l}\text { environmental issues, willingness to invest in environmental businesses and willingness to invest } \\
\text { in environmentally friendly countries. }\end{array}$ \\
\hline $\begin{array}{l}\text { Karna, Hansen, Juslin } \\
(2001)\end{array}$ & $\begin{array}{l}\text { Competitive advantage of the company through respect for the environment. Ecological products } \\
\text { are a must. Proactive entrepreneurs prioritize environmental issues in their marketing studies }\end{array}$ \\
\hline Ferraz et al. (2013) & $\begin{array}{l}\text { Environmental knowledge, paying more for environmentally friendly products, beliefs, feelings. } \\
\text { Caring for environmental degradation, Concern about global warming. Pollution of the } \\
\text { environment. Influence of product prices, perceived quality of environmentally sound products, } \\
\text { concern for the environment. }\end{array}$ \\
\hline $\begin{array}{l}\text { Thogersen,Haugaard \& } \\
\text { Olesen (2010) }\end{array}$ & $\begin{array}{l}\text { Custom in buying products with labels to improve the environment. Consumer orientation in the } \\
\text { purchase of environmental products. Concern about the global environment. }\end{array}$ \\
\hline $\begin{array}{l}\text { Castanho, Spers e Farah } \\
(2006)\end{array}$ & $\begin{array}{l}\text { Recycling reduces pollution. Recycling improves the quality of life. Recycling benefits the } \\
\text { environment. }\end{array}$ \\
\hline
\end{tabular}

Source: Adaptation of Veiga-Neto, Filgueiras, Vasconcelos \& Almeida (2014).

The choice of sample was made based on age groups and reference sites where each generation segment was concentrated, as well as secondary data from articles and theses. By means of a questionnaire on environmental favorability, with 67 questions and tested in previous research (Veiga-Neto, Filgueiras, Vasconcelos \& Almeida 2014), the size of the sample was based on Hair et al. (2008), which indicate a minimum value of five times the number of variables surveyed. According to this reasoning, the sample had a minimum value from 335 respondents in each of the generations Baby Boomers, $X, Y$ and $Z$, totaling a final size of 1,385 respondents. As it is a comparative study between the generations, in which the environmental favorability is observed, the same questionnaire composed of 67 questions was applied in all the generational strata.

In the Baby Boomers generation, the research universe consisted of people from the cities of Natal and Mossoró, Rio Grande do Norte, Brazil and Fortaleza, Ceará, Brazil, as well as clients registered in accounting firms and trade unions, totaling a sample of approximately ten thousand people. Rio Grande do Norte is a Brazilian state located in the Northeast that has 3.4 million inhabitants, I have a Gross Domestic Product (GDP) of US\$ 16 billion, representing $0.9 \%$ of the Brazilian GDP. The state of Ceará, also located in the Northeast, has 9 million habitants and the state's GDP is US\$ 24 billion.

In Generation X, the size of the universe was based on the age range of this generation, indicating an approximate value of 154.168 people, based on the 2010 Census of the Brazilian Institute of Geography and Statistics (IBGE). The sample consisted of 336 people of both sexes, randomly chosen, taking into account the age group of the stratum and the places of consumption or the habitual consumers of consumer classes. In the sample of Generation $\mathrm{Y}$, the universe of the research for this age group has about 220.000 people, for a population of the municipality of Natal estimated at 862.044 habitants in 2014 , according to the IBGE. The sample size followed previous criteria, being selected 336 interviewees, of which 99 came from social networks. In turn, the Generation Z sample was composed of 342 students, randomly selected in high schools.

In this study, as we can see, the samples were chosen in a random manner, according to the propositions of Camponar (2012), which states that one can not make inference about the universe when the sample does not follow this precept. The data that compose this research were collected through Internet. The questions were based on the variables of the studies on environmental favorability established by the authors presented in figure 1 , previously tested and validated. In this case, the Likert scale was used, with 5 items of answers.

The Kaiser-Meyer-Olkin index (KMO) was used to verify if the factor analysis was adequate to be used in the data, pointed out an important value of 0.939 , which refers to the use of factorial analysis in this research. In order to examine the validity of the coefficients, the alpha coefficient, called the Cronbach's alpha, was used, varying from 0 to 1 and, according to Hair et al. (2008), should have a lower variation, in the range of 0.60 to 0.70 , for its acceptability. In the sample treatment, the Cronbach's alpha value of 0.945 was calculated, which represents a strong confidence in the coefficients worked. 


\section{Results}

The values collected were based on the Likert scale, with the numbers varying from 1 to 5 , assuming that the closer to the higher values, the greater the tendency for the environmental favorability of the concern with the environment. With the exception of the Baby Boomers generation, with an average equal to (3.53), all other generations presented a homogeneity in their means, even with values greater than 4 . When comparing the means of the variables of the generations BB, X, Y and Z, through of the Analysis of Variance (ANOVA), with 95\% confidence, a statistically significant difference $(p<0.05)$ was identified in the comparison between the generations studied. Subsequently, the Tukey Test was used to indicate which or which generations had different characteristics when they were purchased with the whole segment. Thus, the Baby Boomers generation is the only one with the lowest statistically significant mean $(p<0.05)$, in relation to the $\mathrm{X}, \mathrm{Y}$ and $\mathrm{Z}$ generations.

The scores of the generations $X, Y$ and $Z$, with respect to the environmental variables with a mean greater than four, assume a tendency to environmental favorability, on the part of the respondents, with a percentage greater than $80 \%$. Although there are some resistances of Generation Y, pointed out by Lu, Bock and Joseph (2013), in the purchase of green products, because they are expensive, their components have the highest environmental score, being corroborated by Ottman 2012), when it considers the leadership of the mentioned generation, the children of the Baby Boomers Generation and the coexistence with the environmental and social concerns of the parents, in the direction of environmental favorability.

Data show that the Baby Boomers generation has a lower commitment to environmental favorability. According to Kotler and Keller (2012); this is a statement found in surveys that point out that young people are more concerned about the environment. Wiernic, Ones and Dilchert (2013) suggest that older people seek a faster pace in their satisfactions, not having to worry about the future of those who, like them, are more concerned about the present, which may be influenced by the shorter life cycle in relation to other generations.

When analyzing the variable it is observed that the variable Q31 - "Environmental responsibility of the company" is the one with the highest value, with an average of close to 5 , representing a value of 4.73 . Next, we have the variable Q7 - "Environmental responsibility of the government" with 4.72. In this way, the larger averages make both government and private initiative responsible for improving environmental issues. For Romeiro (2006), government, companies and NGOs would be responsible for persuading people to adhere to green consumption. According to the author, the population expects greater commitment from the government in the fiscalization, with greater applicability of the legislation that regulates such products.

In the research, it was realized that the consumer should do his part. The variable Q-32 "Environmental responsibility of the consumer" shows that the consumer should engage in the group of responsibility with the environment. In this case, those surveyed are also included, based on the variable Q9 - "Consciousness in saving electricity", with an average of 4.69 and Q32 "Consumer environmental responsibility", which means a framework in the binomial of ecological consciousness and personal liability with correspondence on virtually all other variables. Hamilton (2010) believes that social and cultural issues are important for the awareness and changes of consumer attitudes, in the search for environmental favorability.

Four factor rotations were made with the aim of improving the relationship between factors and variables through factor analysis. According to Corrar, Paulo and Dias Filho (2014), the intention is to increase the explanatory force of the factors, which is stronger from the moment it approaches 1. After the four rounds and elimination of some variables, we reached a result containing nine factors and explanatory variance of $56.79 \%$ as shown in table 1 . 
Table 1: Distribution of environmental factors according to the generations

\begin{tabular}{|c|c|c|c|c|c|}
\hline \multirow[b]{2}{*}{ Environmental Factors } & \multirow[b]{2}{*}{ All Generations } & \multirow[b]{2}{*}{ Baby Boomers } & \multicolumn{3}{|c|}{ Generations } \\
\hline & & & $\mathbf{x}$ & & $\mathbf{Z}$ \\
\hline Environmental responsibility of society & 4.72 & 4.77 & 4.74 & 4.70 & 4.65 \\
\hline Environmental awareness $\left(^{*}\right)$ & 4.62 & 4.54 & 4.68 & 4.67 & 4.60 \\
\hline Effective pro-environment actions & 4.29 & 4.10 & 4.33 & 4.37 & 4.36 \\
\hline Concern about the rubbish issue & 4.18 & 3.72 & 4.34 & 4.28 & 4.37 \\
\hline Recyclable Adoption & 4.14 & 3.60 & 4.41 & 4.30 & 4.25 \\
\hline Feelings favorable to the environment $\left(^{*}\right)$ & 3.79 & 3.00 & 3.85 & 4.07 & 4.24 \\
\hline Conscious consumption $\left(^{*}\right)$ & 3.51 & 2.76 & 3.69 & 3.77 & 3.84 \\
\hline Environmental influences on the purchase decision $\left({ }^{*}\right)$ & 3.26 & 2.55 & 3.44 & 3.66 & 3.33 \\
\hline Credibility in environmental communication $\left(^{*}\right)$ & 3.07 & 2.57 & 3.09 & 3.40 & 3.22 \\
\hline Average & 3.95 & 3.51 & 4.06 & 4.14 & 4.09 \\
\hline
\end{tabular}

$\left.{ }^{*}\right) p<0.05$

\section{Source: Search data.}

It can be seen that the Baby Boomers generation presents, on average, the lowest value among the other generations in terms of environmental favorability. Generations $X, Y$ and $Z$ have a homogeneous behavior, placing themselves at a level of more than $80 \%$ in the direction of environmental favorability.

Five factors present evidence of a level of significance: "Environmentally friendly feelings", "Environmental Influences in Purchase Decisions", "Environmental Consciousness", "Conscious Consumption" and "Credibility in Environmental Communication". The small number of variables that make up the sample of the factors, "Concern about the issue of garbage" and "recycling Adoption", may have contributed to not identify the statistical difference between Generation Baby Boomers and other generations demonstrated the calculated averages.

Among the nine related factors, the variable "Environmental Responsibility of the Company" is identified as having the highest average (4.72) in the total generation, with high averages for the Baby Boomers, $X, Y$ and $Z$ generations. The score shows that it represents more than $90 \%$ of respondents, which may suggest contributing to a sustainability of the planet in which they live. Thus, Laroche, Bergeron and Barbaro-Forleo's (2001) thinking is confirmed, when in his research the seriousness that society has towards the environment is stated, even if it is prepared to pay more for a product green. The companies also offer their social contribution, without harming the environment, by adopting an ethical stance, not behaving, according to Romeiro (2006), only philanthropically. There is, therefore, a joint alliance between companies, government and consumers, in search of an environment with greater protection to nature.

The second highest score was the "Environmental Awareness", (4.62), showed a commitment to the environment from $90 \%$ in all the generations studied. Through analysis of variance (ANOVA) at a significance level of $5 \%$, it suggests a statistical difference when compared to the means of all generations within the "Environmental Consciousness" factor. Baby Boomers have the lowest average of all generations analyzed. Among those interviewed, there is concern about the future of the planet regarding climate change, the disappearance of forests and pollution. As postulated by Schons (2012), the deforestation of forests through mechanized agriculture leads to global warming, torrential rains, melting of poles and increasing poverty in unequal competition. For the author, society, especially those less enlightened environmentally, will possibly suffer from the phenomena of nature.

Among the lower averages presented by environmental factors, there is initially the inherent factor "Credibility in Environmental Communication", linked to the variables of belief and trust in advertising and label ads that obtained a score of 3.07, being followed in every segment of the generations. It was verified through Analysis of Variance (ANOVA), which the Baby Boomers Generation with a mean (2.57), differs statistically from the younger generations. The Tukey test was used to point out the differences found in the means presented through ANOVA. The result of the test identified that the Baby Boomers Generation differs statistically at the significance level of 
$5 \%$ of Generation $Y$ and Generation $Z$, considered as younger generations, who were born with quick and easy access to technological information. In this study, the generations BB and $X$, considered as the generations of greater ages, exposed distrust in allusion to the labels. For Thogersen et al (2010) consumers with greater knowledge are less skeptical about the information contained in the labels.

Another low average factor (3.26) is the one that deals with "Environmental influences in the purchase decision", in which are the variables related to the influences that interfere with the consumer to opt for an environmental product. In this context, consumers are influenced by variables such as: environmental certifications of the company, media, label, friends and advertising, but not so relevant to other factors. Table 8 shows that all generations have low means, and again the Baby Boomers Generation with the lowest average among them (2.55). The analysis of variance (ANOVA) was carried out at the $5 \%$ level, it was verified that the Baby Boomers Generation suffers the least environmental influence in the purchasing decision in relation to the others.

The "Conscious consumption" with a mean (3.51) seems to indicate that the interviewees are environmentally aware (4.62) but in practice do not present a behavior that can contribute to the sustainability of the planet, and there is a gap between the consciousness in favor of the environment and individual conscious consumption for the betterment of the planet. In the segment of the generations, the Baby Boomers presents a low score (2.76), where a statistically significant difference is verified between this generation composed of older people and the generations $\mathrm{X}, \mathrm{Y}$ and Z. In their research Larroche, Bergeron and Barbaro-Forleo (2001) identified people with difficulties in maintaining a commitment to the environment, with attitudes of inconvenience in collaborating with nature. Hence the importance of green marketing work influencing through communication by acting to make people aware of a better world environmentally. Thus, factors such as "Environmental influences in the purchase decision" (3.26) and "Credibility in environmental communication", (3.07) with lower environmental means, may have a greater commitment to the environment. Thus, the variables were grouped into factors. The factors of environmental favorability were chosen as:

Factor 1. Environment-Friendly Feelings, in which the variables are related to the studies of Larroche, Bergeron and Barbaro-Forleo (2001), in their totality, on the attitudes, values and environmental responsibilities of the consumers;

Factor 2. Environmental Influences in the Purchase Decision, according to Martinez (2010), the variables that influence consumers in purchasing decisions may indicate the trend towards environmental favorability;

Factor 3. Environmental Awareness, in the studies on environmental behavior, Stern (1999) identified that incentives and information could be more applied, making consumers aware of the implications of deforestation, pollution and climatic consequences that affect nature;

Factor 4. Effective Actions Pro-environment. In this factor, the variables are related to an active awareness on the part of the consumers. According to Larroche, Bergeron and BarbaroForleo (2001), the concern of consumers is to save electricity, water and recycling with a view to the sustainability of the planet;

Factor 5. Conscious consumption. The variables of this factor are related to the studies of Straughan and Roberts (1999) and Larroche, Bergeron and Barbaro-Forleo (2001). For the authors, consumers are involved in ecologically conscious consumption, they present changes in their consumption behavior in favor of the environment;

Factor 6. Adoption of Recyclables. In this factor were condensed the variables of the research of Larroche, Bergeron and BarbaroForleo (2001), when the consumers' willingness to pay more for products related to the environment and with recycling behavior in order to contribute to the reduction of products that attack nature;

Factor 7. Credibility in Environmental Communication. The variables that make up this factor are related to consumers' skepticism regarding the labeling of environmental products. For Mohr, Webb and Harris (2001) consumer mistrust in the labeling and advertising of environmental products suggests to green marketing operators better disclosure of their products, causing purchasers to purchase products from non-greenwashing companies; 
Factor 8. Concern about the Garbage Question. In this factor are added the variables studied by Mohr, Webb and Harris (2001), on the concern of the consumers with the discard of the products both individually and of the society, being the question of garbage an important element in the research of these authors. For many of these, the purchase of products from a particular company is conditioned on the company's interest in contributing to the environment;

Factor 9. Environmental Responsibility of the Company. It was the factor with the greatest measure among all, in which consumers point out the responsibility of government, society and individual consumer commitment in preserving the environment.

\section{Conclusion}

In this research, factors related to environmental favorability were identified in the four generations studied, comparing them with those linked to all generations and showing a homogeneity in the mean of environmental variables. In segmentation by generations, the Baby Boomers generation presented the lowest mean when confronted with Generations X, Y and Z.

Consumers' behavior regarding environmental favorability was analyzed, which showed a statistically significant difference in the average of the Baby Boomers Generation, which was the lowest among all generations. Generations $X, Y$ and $Z$ had, on average, a percentage greater than $80 \%$ for this factor. This percentage suggests the population's concern with environmental issues, with Generation $Y$ exposing the highest average for environmental favorability. In a way, this indicates the concern of a young generation with the environment, contributing to an environmental sustainability of the planet.

In the analyzes of the averages were indicated those that had the greater and less tendency for the environmental favorability, pointing a percentage greater of $80 \%$ for the generations $X, Y$ and Z. Against Baby Boomers Generation with the lowest average 3.53, the which represented a certain statistical significance taking into account the younger generations. Four rotations were performed, starting with 15 components, until the ideal number of 9 components were reached, which, after clustering, became environmental factors.

Thus, this research has relevance for researchers, society and academia, since it allowed to identify the most important factors that explain the variables of environmental favorability of consumers of the generations $B B, X, Y$ and $Z$. Given the information provided in this study, environmental marketing professionals will be able to direct their plans in search of strategies that can generate competitive advantage for their companies. In addition, the credibility advertised by consumers in Non-Governmental Organizations (NGOs) and government institutions can collaborate in the implementation of public policies aimed at environmental favorability.

New research may be carried out with the intention of recognizing and establishing other variables that are linked to the competitiveness construct in conjunctures that cover environmental issues or investments in environmental businesses. And still invest the gap between having environmental awareness and being a conscious consumer.

\section{References}

Ali, A., Khan, A. A., Ahmed, I., \& Shahzad, W. (2011). Determinants of Pakistani consumers' green purchase behavior: Some insights from a developing country. International Journal of Business and Social Science, 2(3), 217-226.

Castanho, S. C. R., Spers, E. E., \& Farah, O. E. (2006). Custos e benefícios para o consumidor na ação da reciclagem. Revista de Administração Mackenzie, 7(4), 78-98.

Ceretta, S. B., \& Froemming, L. M. (2011). Geração Z: Compreendendo os hábitos de consumo da geração emergente. RAUnP, 3(2), 15-24.

Corrar, L. J., Paulo, E., \& Dias Filho, J. M. (2014). Análise multivariada: para os cursos de administração, ciências contábeis e economia. São Paulo: Atlas, 280-323.

Feitosa, W. R. (2009). A segmentação de mercado por meio de coortes e gerações (Doctoral Thesis, Universidade de São Paulo).

Foscht, T., Schloffer, J., Maloles III, C., \& Chia, S. L. (2009). Assessing the outcomes of Generation-Y customers' loyalty. International journal of Bank marketing, 27(3), 218-241. 
Neves Garcia, M., Silva, D. D., Silva Pereira, R. D., Bedinelli Rossi, G., \& Minciotti, S. A. (2008). Inovação no comportamento do consumidor: recompensa às empresas socioambientalmente responsáveis. RA/Revista de Administração e Inovação, 5(2), 44-61.

Glass, A. (2007). Understanding generational differences for competitive success. Industrial and commercial training, 39(2), 98-103.

Hamilton, C. (2010). Consumerism, self-creation and prospects for a new ecological consciousness. Journal of cleaner production, 18(6), 571-575.

Instituto Akatu (2013). Assimilação e perspectivas do consumo consciente no Brasil: percepção da responsabilidade social empresarial pelo consumidor brasileiro.

Instituto Akatu (2002). Os jovens e o consumo sustentável: construindo o próprio futuro?

Kotler, P., \& Keller, K. L. (2012). Administração de marketing.

Ladeira, W. (2010). Estilos de tomada de decisão: uma investigação em gerações diferentes. Revista de Administração da UNIMEP, 8(3).

Laroche, M., Bergeron, J., \& Barbaro-Forleo, G. (2001). Targeting consumers who are willing to pay more for environmentally friendly products. Journal of consumer marketing, 18 (6), 503-520.

Madahi, A., \& Sukati, I. (2012). The effect of external factors on purchase intention amongst young generation in Malaysia. International Business Research, 5(8), 153.

Mandhlazi, L., Dhurup, M., \& Mafini, C. (2013). Generation Y Consumer Shopping Styles: Evidence from South Africa. Mediterranean Journal of Social Sciences, 4(14), 153-164.

Martinez, M. F. (2010). Variáveis explicativas da favorabilidade ambiental do consumidor: uma investigação na cidade de São Carlos (Doctoral thesis).

McCrindle, M., \& Wolfinger, E. (2014). The ABC of XYZ: Understanding the global generations. The ABC of $\mathrm{XYZ}$.

Osajima, K., Sternquist, B., \& Manjeshwar, S. (2010). Japanese materialism: A comparison between the new breed and second baby-boomer age-cohorts. Journal of Asia Business Studies, 4(2), 57-72.

Ottman, J. A. (2012). As novas regras do marketing verde: estratégias, ferramentas e inspiração para o branding sustentável. São Paulo: M. Books do Brasil.

Romeiro, M. D. C. (2006). Um estudo sobre o comportamento do consumidor ambientalmente favorável: uma verificação na Região do ABC Paulista (Doctoral thesis, Universidade de São Paulo).

Royne, M. B., Levy, M., \& Martinez, J. (2011). The public health implications of consumers' environmental concern and their willingness to pay for an eco-friendly product. Journal of Consumer Affairs, 45(2), 329343.

Schlegelmilch, B. B., Bohlen, G. M., \& Diamantopoulos, A. (1996). The link between green purchasing decisions and measures of environmental consciousness. European journal of marketing, 30(5), 35-55.

Schons, S. M. (2012). A questão ambiental e a condição da pobreza. Revista Katálysis, 15(1).

Solomon, M. R. (2008). O Comportamento do Consumidor-: Comprando, Possuindo e Sendo. Bookman Editora.

Straughan, R. D., \& Roberts, J. A. (1999). Environmental segmentation alternatives: a look at green consumer behavior in the new millennium. Journal of consumer marketing, 16(6), 558-575.

De Toni, D., Larentis, F., Mattia, A. A., Gilioli, R. M., \& Milan, G. S. (2013). Consumo consciente e seus impactos sobre valor percebido e lealdade em produtos ecologicamente corretos: proposição e teste de um modelo teórico. Revista Gestão Organizacional, 6(2).

Thøgersen, J., de Barcellos, M. D., Perin, M. G., \& Zhou, Y. (2015). Consumer buying motives and attitudes towards organic food in two emerging markets: China and Brazil. International Marketing Review, 32(3/4), 389-413.

Vaz, C. (2011). Os 8 Ps do Marketing Digital: O guia estratégico de marketing digital. Novatec Editora.

Veiga-Neto, A. R., Filgueiras, C. R. M., Vasconcelos, C. R. M., \& de Almeida, S. T. (2014). Marketing verde aplicado à estratégia como prática: análise de variáveis na visão de empreendedores. RAUnP-ISSN 1984-4204, 6(2), 23-37.

Wiernik, B., S. Ones, D., \& Dilchert, S. (2013). Age and environmental sustainability: a meta-analysis. Journal of Managerial Psychology, 28(7/8), 826-856.

Williams, K. C., \& Page, R. A. (2011). Marketing to the generations. Journal of Behavioral Studies in Business, 3,1 . 